\title{
Trampolinhuset: Kulturelt rum som politisk modspil
}

Signe Brink Wehl, ph.d., Head of Arts, Roskilde Festival

Trampolinhuset i Københavns Nordvestkvarter er et mødested for asylansøgere, aktivister og generelt alle interesserede. Huset startede i 2010 som et kunstprojekt, der skulle scette fokus på forholdene i de danske flygtningelejre, og huset skulle fungere som et fristed og vise et alternativ til udlaendingepolitikkens rammer. I dag eksisterer Trampolinhuset stadig, og flygtningedebatten er et mindst ligeså aktuelt omdrejningspunkt $i$ den politiske debat. Med begrebet Critical Spatial Practice argumenterer arkitekturprofessor Jane Rendell (2006) for, at arkitektur og rumlig kunst har et scerligt potentiale for at skabe kritik, frirum og forandring. Denne artikel diskuterer med udgangspunkt i Trampolinhuset og Rendells teoretiske koncepter, hvordan kulturelt rum kan vare politisk modspil, og hvordan kunst kan spille en rolle heri. Konkret undersøges det i hvilket omfang og hvordan Trampolinhuset som rum og som kunstprojekt har varet politisk aktør og forandringsagent.

\section{Baggrund}

Trampolinhuset i Københavns Nordvestkvarter er et forsamlingshus for asylansøgere, aktivister og alle, der ønsker at engagere sig i husets aktiviteter. Oprindeligt startede huset som et kunstprojekt. Det var en kritik af forholdene i de danske flygtningelejre, og huset skulle fungere som et fristed og vise et alternativ til udlændingepolitikkens rammer.

Den oprindelige gruppe af initiativtagere til huset var de to kunstnere Morten Goll og Joachim Hamou foruden kurator Tone O. Nielsen samt et bredt netværk af kunststuderende, aktivister og asylansøgere. Projektet opstod i kølvandet på den store civile ulydighedsaktion Luk Lejren i 2008, der var en aktion, som rettede kritik mod forholdene i de danske asylcentre. Gruppen ville som en del af deres kunstneriske praksis forbedre rammer og vilkår på asylcentrene. Fokus var i udgangspunktet på forbedring af det fysiske miljø på asylcentrene. De ville starte et sted, hvor de mente, at de kunne gøre en mærkbar forskel (Blankholm 2011).

Gruppens vision var at bruge et æstetisk greb og en socialt engageret metode til at forbedre rammerne på centrene. Arkitektonisk indretning, maling af rummene, billeder på væggene og inddragelse af beboere i den rumlige forbedring skulle skabe et bedre, mere inkluderende og sanseligt miljø og dermed forhåbentligt forbedre livskvaliteten for 
asylansøgerne på centrene. I tråd med ideen om, at kunst og indretning på hospitaler kan have en helbredende effekt, skulle et visuelt skønnere miljø, som beboerne kunne have indflydelse på, have en positiv virkning på beboernes tilværelse på centrene.

Allerede i opstarten af projektet begyndte kunstgruppen dog at tvivle på, om maling og møbler ville give den ønskede effekt. Kunne det indretningsorienterede greb være med til at løse kerneudfordringen på asylcentrene? Der var overskyggende og mere alvorlige udfordringer, som fik ideen om forskønnelse til at blegne. Beboerne på centrene savnede en grundlæggende oplevelse af værdighed, selvstændighed og mulighed for engagement og meningsfyldte aktiviteter i deres egen hverdag. Yderligere beskrev beboerne en tilstand af afmagt og modløshed forårsaget af uvisheden om tvangsudvisning. Det faktum, at beboerne på centrene var isoleret fra det omgivende samfund, og hverken måtte arbejde eller uddanne sig, skabte en stemning af magtesløshed, da de ikke havde mulighed for at engagere sig i det miljø og det samfund, som de nu var en del af (Goll 2017).

En arbejdsgruppe udgjorde tænketanken og strategien, som de betegnede som Asyl Dialog Tanken. Her er den grundlæggende tanke, at asylansøgerne selv er drivkraften i arbejdet for bedre vilkår. Asyl Dialog Tanken blev forløberen til Trampolinhuset. Her formuleredes gennem workshops i asylcentrene bud på, hvad der kan hjælpe asylansøgere ud af den situation, de befinder sig i.

"Det, som asylansøgerne fortalte os i disse workshops, gjorde os klogere på hvad der er galt med centrene, og hvad der er galt med lovgivningen. Ud af det kom ideen om, at vi bliver nødt til, så længe folk er fanget i det her system og venter på en form for afgørelse - asyl eller udvisning - at etablere et tredje rum. Et rum hvor asylansøgere og folk med statsborgerrettigheder kan mødes på lige fod, med lige rettigheder, og arbejde for bedre vilkår. Det blev så til ideen om Trampolinhuset." (Initiativtager og kurator Tone O. Nielsen i interview med Klokhøj 2011)

Kunstnergruppen nåede i samråd med asylansøgere på Center Sandholm og Kongelunden til en erkendelse af, at det ikke var asylcentrenes rammer, men derimod udlændingepolitikkens restriktioner, der fastholdt asylansøgerne i en passiv tilstand. Tilstanden for asylansøgerne var altså i højere grad fremkaldt af de juridiske rammer, de befandt sig i. Beboerne havde ifølge lovgivningen ikke mulighed for at tage et job og på den måde blive engageret $\mathrm{i}$ det danske samfund. Ligeledes havde asylansøgernes børn ikke mulighed for at gå i skole eller daginstitutioner og dermed skabe et meningsfuldt hverdagsliv (Blankholm 2011). Ifølge kunstnerne ville det virke som at sminke den passiviserende situation asylansøgerne befandt sig i ved blot at ændre på det fysiske rum på centrene. Ny indretning af de eksisterende centre blev således ikke omdrejningspunktet for den kunstneriske proces.

Kunstnerne ønskede at skabe et alternativt rum og samtidig havde deres visioner forskudt sig fra en fysisk forandring af det eksisterende til at skabe et alternativ, der kunne 
bringe beboerne ud af den passive offerrolle og tilbyde et decideret alternativ til asylcentrene (Goll 2017). Derfor opstod visionen om et tredje rum; et alternativt sted, et fristed og en moddiskurs, der kunne være afsæt for asylansøgere til at indgå i det danske samfund med værdighed, frihed og mod; et modspil, der arbejder for et andet politisk rationale end den gældende og lovgivende diskurs, der satte rammerne for asylcentrene. Det blev således til Trampolinhuset og ideen om trampolinen som fundament, der giver energi til at være afsæt for en ny livsbane (Blankholm 2011).

Denne artikel undersøger, hvordan kulturelle moddiskurser som Trampolinhuset kan skabe nye politiske frirum. I denne artikel bruges rumlige konceptuelle begreber om etablering af frirum og kritik primært fra Jane Rendells koncept Critical Spatial Practice (2006) og supplerende fra byrumssociologen Ole B. Jensen (2004) og kunsthistoriker Miwon Kwon (2004) til at undersøge den rumlige kunsts særegne kritiske potentiale som politisk modstand. Afslutningsvis diskuterer artiklen, med perspektiver fra Claire Bishop, Chantal Mouffe og Andrea Phillips, kunstens kritiske og socialt engagerede rolle, samt hvorledes kunsten kan og bør indtage en socialt engageret og politisk rolle i samfundet.

\section{Trampolinhuset som politisk rum}

Trampolinhuset har - til trods for det eksperimentelle udgangspunkt - eksisteret som et medborgerhus for asylansøgere i snart 9 år. Dagligt frekventerer mennesker fra over 40 forskellige nationaliteter huset. Det har haft lokation forskellige steder i København, men grundideen er uforandret: Et medborgerhus og et fristed for asylansøgere, aktivister og andre borgere i Danmark, der ønsker at engagere sig i husets aktiviteter (Bonde 2011). Der kommer stadig flygtninge til Danmark, og derfor er flygtningedebatten stadig et aktuelt omdrejningspunkt for politisk debat i Europa og i Danmark. Huset har fra 20102015 været støttet af OAK Foundation og fra 2014 af Udlændingestyrelsen sammen med en række private fonde, Kultur og Fritidsudvalget samt Områdefornyelsen i Københavns Kommune (Trampolinhuset 2018).

Initiativtagerne bag trampolinhuset bruger i dag særligt tre forskellige metodiske greb til at skabe den forandring, som de ønsker, at Trampolinhuset skal være katalysator for. En metode er skabelsen af et demokratisk medborgerskab, som giver den enkelte forbedrede muligheder for at indgå i en demokratisk debat. En anden metode er at bruge kunst som en forandringsagent og skabe forandring af den politiske situation gennem kunsten. Og en tredje metode fokuserer på at åbne huset op gennem strategiske partnerskaber med fonde, institutioner, organisationer og kommune. 


\section{Demokratisk medborgerskab}

I huset arbejdes ud fra et holistisk perspektiv, hvor visionen overordnet er et nyt asylsystem, der giver alle lige muligheder for at deltage i samfundet. Denne metode fokuserer på at styrke brugerne gennem deres eget engagement. Derfor er der en vifte af aktiviteter, der sigter mod at styrke brugerens muligheder for netop at deltage i samfundet. Der er aktiviteter såsom jobtræning, uddannelse, demokratisk praksis, systemforståelse og juridisk rådgivning. Derudover fokuseres der på at etablere et socialt netværk for at styrke den enkeltes forudsætninger for integration i samfundet.

Husets daglige aktiviteter består primært af brugerdrevne initiativer. Brugerne er selv med til at sætte rammerne om hverdagen i huset. Der holdes ugentlige husmøder og fællesspisningsarrangementer, hvor der diskuteres alt fra global flygtningepolitik til organisering af dagligdagen i huset. Desuden tages der beslutninger om nye aktiviteter lige såvel som den strategiske udvikling af huset drøftes. Huset har dagligt åbent og rummer en skrædder, et cykelværksted, en frisør samt børneaktiviteter og -pasning og sågar en Kvindeklub. Huset har et fælles køkken, hvor der er en madklub og et cateringfirma, Sisters Cuisine, som er drevet af en gruppe kvindelige brugere i huset. Brugerne får således både mulighed for at sætte egne kompetencer i spil, danne fællesskaber og planlægge kollektive aktiviteter. Det er således en del af metoden at styrke det enkelte individ i forhold til muligheden for at udfolde dets eget potentiale (Hansen 2018).

Foruden de daglige aktiviteter findes en række mere strategiske initiativer fra husets side. De har til formål at understøtte brugerne ved at styrke dem i mødet med det danske samfund samt at kaste et kalejdoskopisk lys på migrationsproblematikker (Goll 2016). Der er etableret sprogskole, hvor brugerne selv kan undervise i og modtage undervisning i dansk, engelsk, arabisk, farsi og fransk. Der afholdes demokratiworkshops og der tilbydes både mulighed for arbejds- og uddannelsespraktik i huset, der kan føre til praktik på arbejdsmarkedet. Desuden har huset egen retshjælp, der drives af frivillige jurister. De kan hjælpe asylansøgerne ift. de udfordringer, de møder i det danske retssystem. Der er en frivillig drevet læge- og psykologklinik. Asylansøgere har adgang til det danske sundhedsvæsen, men forankringen af klinikken i huset har stor relationel betydning, da mange kommer med en mistillid til systemet og derfor kan have svært ved at opsøge lægehjælp i det 'almindelige' sundhedssystem. Her er Trampolinhusets klinik et tilbud i velkendte rammer, da det er integreret i deres hverdag i huset (Kristensen 2016).

Disse aktiviteter har til formål at muliggøre deltagelse i samfundet for det enkelte menneske. Husets leder Morten Goll lægger i en artikel om Trampolinhusets demokratiske model for medborgerskab vægt på følgende elementer:

"Vi har gennem årene udviklet en model, der hviler på tre søjler. 'Socialt netværk', 'Demokratisk Medborgerskab' og 'Rådgivning/Systemforståelse'. Ved at give muligheden for et socialt netværk, som også omfatter danskere, vokser asylansøgere ind i rollen som medborgere uden CPR- 
numre. Mange af vores frivillige fra asylcentrene udtrykker, at i Trampolinhuset er man et ganske almindeligt menneske, mens man i asylcenteret er et nummer i en statistik. Asylsystemet behandler dig som klient, mens Trampolinhuset giver dig mulighed for at træde i karakter som et individ med resurser, som fællesskabet har brug for.” (Goll 2017)

Tanken her er, at muligheden for engagement og demokratisk medborgerskab for asylansøgerne vil øge deres integration i det danske samfund.

\section{Kunst som forandringsagent $i$ Trampolinhuset}

Trampolinhuset udsprang som et kunstprojekt, og kunsten spiller forsat en central rolle i huset ved at være en socialt engageret praksis. En praksis der ved at formidle kunst både kan give husets brugere nye kundskaber og åbne huset for omverdenen.

I 2014 blev den selvejende institution udstillingsstedet Camp-Centre for Arts on Migration Politics en indlejret og fast del af huset. På de ugentlige husmøder havde brugerne $\mathrm{i}$ en længere periode drøftet de muligheder, et kunstcenter integreret i huset kunne skabe. Visionen for Camp var udviklet af kuratorkollektivet Kuratorisk Aktion, som består af Frederikke Hansen og Tone O. Nielsen. Sidstnævnte er også en af initiativtagerne til Trampolinhuset. Deres udgangspunkt var at skabe et analyserum for lejr- og flygtningelivet i Trampolinhuset. Her inviteres kunstnere, der adresserer migrationsproblematikker, til at lave udstillinger og aktiviteter. Her diskuteres emner som fordrivelse, flugt og migration gennem kunst udøvet fortrinsvist af mennesker, der selv har været på flugt eller er migreret. Kuratorisk Aktion ønsker gennem kunst at fremme forståelsen mellem fordrevne mennesker og de samfund, der modtager dem. Visionen er endvidere at give den kunst, der adresserer migrationsproblematikker, en platform og et diskussionsrum. Desuden er der en tro på, at kunst kan skabe forandring og være udgangspunkt for meningsfyldte samtaler og processer, der kan anspore nye visioner for migrations-, flygtninge- og asylpolitik. I Camp vises primært visuel kunst og performance, der ikke kræver særlige sprogkundskaber (Hansen 2018).

Kunsten har, ligesom den havde ved projektets udspring, stadig en særlig plads i huset. Det har været en præmis for Camp at insistere på, at rummet for kunst i Camp er politisk, ligesom det er i Trampolinhuset. Til forskel fra den traditionelle forståelse om udstillingsrum på museer og gallerier er rummet i Camp altid og allerede politisk. På linje med Trampolinhuset har Camp taget stilling til, at de er uenige i de aktuelle lovgivningsmæssige rammer for migranter. Camp tror på, at for at forstå samfundsstrukturernes dynamikker, bør der skabes indsigt i de samfundsgrupper, der har de dårligste vilkår. I Camp sættes kunsten således i en politisk kontekst, hvor den kan give en anden vinkel på migrationsproblematikker (Hansen 2018).

Det er et ønske hos Camp om at opdyrke en langvarig relation til et bredt publikum og herved medvirke til, at huset kan åbne sig for omverdenen. Kunstprojekter i Camp 
fører til udstillingsåbninger, omvisninger og relaterede projekter, der ikke kun åbner stedet op for de involverede kunstnere og engagerede fra Trampolinhuset, men også giver anledning til at invitere omverdenen, lokale og kunstfaglige interessenter indenfor i huset og dermed udbrede kendskabet til huset. Samtidig er der et ønske om, at der etableres en aktuel og levende dialog med omverdenen om kunstens potentiale i et politisk rum. Kunsten kan belyse alvorlige emner stemningsfyldt, også for dem i huset, der måske ikke vidste, at de var interesseret $i$ at opleve kunst (Hansen 2018).

\section{Forandring gennem strategiske partnerskaber}

Den grundlæggende metodiske ide i Trampolinhusets vision om at være et politisk modspil er, at huset ikke må lukke sig om sig selv. For at skabe forandring på et niveau, hvor det påvirker den samfundsmæssige dialog søger Trampolinhuset også at interagere med det omgivende samfund. Gennem samarbejder med kulturinstitutioner, virksomheder, fagforeninger, NGO'er, fonde, medier, kommuner og staten om aktiviteter udbredes visioner og metoder. Disse udadvendte aktiviteter forberedes "hjemme" i Trampolinhuset med workshops om kampagner og organisering. På denne måde bryder huset ud af de vante rammer og benytter andre kulturelle formater som platform. Trampolinhusets alternative rum kan præsenteres og brugerne kan engageres i nye kontekster. Eksempelvis er dette sket på spillestedet Loppen, ved deltagelse på Folkemødet og ved samarbejde med Roskilde Festival, hvor folkene bag Camp i 2018 havde kurateret aktivistgruppen Gulf Labor Coalition. Denne gruppe er en sammenslutning af internationale kunstnere, der arbejder mod underbetaling af arbejdskraft ifb. bygning af nye kunstmuseer. Blandt andet har de besat byggepladsen i forbindelse med opførslen af Guggenheim i Abu Dhabi. Dette er et eksempel på, at Trampolinhusets brugere kan gå sammen med internationale aktivister og skabe et kunstnerisk afsæt for at kæmpe for lige vilkår for mennesker på tværs af grænser. Derved skaber Trampolinhuset og Gulf Labor Artist Coalition et fælles opråb om ulighed overfor minoritetsgrupper. På den måde præsenteres deres moddiskurs på en bredere platform, hvorved de opnår en langt større berøringsflade end indenfor Trampolinhusets vægge.

En central strategisk samarbejdspartner for Trampolinhusets er Københavns Kommune. Trampolinhuset er placeret i Københavns Nordvestkvarter og samarbejder med kvarterets kommunale byudviklingsinitiativ Områdefornyelsen. Trampolinhusets og Camps aktiviteter støttes af Københavns Kommune, og huset opfattes som et initiativ, der giver værdi til udviklingen af kvarteret, som et socialt og kulturelt samlingspunkt, der appellerer til engagement i civilsamfundet og på den måde giver en værdi for det lokalområde, som det er placeret i (Københavns Kommune 2018).

Er det stadig muligt for projektet at være et kritisk modspil til samfundet og de gældende rammer for migranter, når det har et samarbejde kommunen? Spørger vi stifterne, ser de forsat Trampolinhuset som et fristed i fysisk form, og mener ikke, at samarbejdet med strategiske partnere såsom fonde, etablerede institutioner og Københavns 
kommune begrænser mulighederne for at skabe forandring. Tværtimod er de bevidste om, at der er en stor værdi i at samarbejde, og til trods for uenighed med systemet, tror de på, at der er et større forandringspotentiale, hvis Trampolinhuset kan skabe attraktive og kritiske projekter i samspil med andre aktører (Hansen 2018). Selvom det alternative politiske rum i Trampolinhuset er skabt som en modreaktion mod de gældende rammer for migranter, er initiativtagernes forandringsmetode samtidig baseret på engagement med aktører, som er en del af disse rammer, såsom Københavns Kommune.

\section{Undersøgelse af den rumlige kunsts kritiske potentiale}

Som nævnt opstod visionen om Trampolinhuset, da kunstnere ønskede at skabe et alternativt rum for asylansøgere i Danmark. Den kunstneriske praksis arbejder her som en kritisk reflekterende spatial praksis. Netop den kunstneriske spatiale praksis kan noget særligt som kritisk agent, fastslår den britiske kunst- og arkitekturprofessor Jane Rendell (2006) i bogen Critical Spatial Practice - A space between. Rendell definerer, at critical spatial practice er en rumlig interdisciplinær kunstnerisk praksis, der forholder sig til og intervenerer i det rum, den er tilstede i. Trampolinhuset beskrives af stifterne som et frirum fra de rammer, der opleves på asylcentrene. Rendell argumenterer for at der kan skabes kritik og frirum gennem spatial intervention. Denne intervention udvisker grænsen mellem kunst og arkitektur og undersøger nye forhold mellem kritisk teori, rumlig kunst og arkitekturpraksis. Rendells udgangspunkt er kritisk teori og kunst- og arkitekturanalyse med et historisk udgangspunkt i 1960erne. Hun bringer kritisk teori og avantgardistisk kunst i spil for at belyse det kritiske potentiale, som hun mener, at den spatiale kunst og arkitektur har, når den undersøger de relaterede forhold mellem kunst og arkitektur i det private og i det offentlige rum samt $\mathrm{i}$ teori og i praksis.

Hun argumenterer for, at denne praksis er særligt interessant, da den tillader nye forbindelser mellem kunst og arkitektur, der kan intervenere i det offentlige rum og $\mathrm{i}$ situationer, hvor der kan skabes et rum for refleksion. Det er en praksis, som er særligt engageret og responderer på sociale og politiske agendaer gennem æstetiske virkemidler (Rendell 2006, 9-11). Denne type kunst kan ved dens spatiale tilstedeværelse manifestere sig både i tid og sted samt tilføre nye og kritiske refleksioner til steder, situationer og aktuelle samfundsforhold.

Rendell fremlægger, at kunst, der er placeret uden for kunstinstitutionens hvide vægge, har mulighed for at respondere på situationer og stedsspecifikke problematikker med en kritisk tilgang. Her kan værkets eller projektets rumlighed adressere de aktuelle problemstillinger ved rumligt at forholde sig til dem. Uden for galleriets ramme er kunst nødt til at engagere sig $i$ andre diskurser end kunstinstitutionens og påtager sig derved en mere engageret og intervenerende rolle i konteksten og samfundet. Denne rolle er traditionelt set forbeholdt arkitekturens undersøgende tilgang til det rum, som den sætter ramme omkring. Imidlertid har kunsten et iboende kritisk potentiale i dens uafhængighed 
af at servicere funktionelle behov, som arkitekturen ofte har som opgave, netop derfor kan kunst og arkitektur supplere og udvide hinandens potentiale (Rendell 2006).

Rendell foreslår, at man forstår rumlig kunstnerisk praksis, som en hybrid mellem kunst og arkitektur, der har et særligt potentiale, som kan forløses og skabe frirum til forandring, når rumlighed og kritik kombineres til en nærværende og kritisk praksis. Ofte opleves det, at kunst i det offentlige rum forventes at tjene et formål såsom at udføre en social funktion eller lindre sociale problemer. Derudover har den rumlige kunst et yderligere potentiale ved at kunne agere kritisk og udfordre både kontekst og ramme for et givent projekt (Rendell 2006, 4). Kunsten kan således overfor samfundet reflektere og give modspil.

Når vi betragter Trampolinhuset ud fra Rendells perspektiv, så er det selve etableringen af et alternativt rum, der er eksemplet på kritisk rumlig praksis. Trampolinhuset startede som et kunstprojekt med et ønske om at skabe forandring gennem kunstneriske greb. Det udviklede sig derigennem til et socialt og rumligt projekt ved at skabe et medborgerhus, der opererer som et alternativ til det eksisterende rum, som asylansøgere tilbydes - altså asylcenterets fysiske og strukturelle rammer og begrænsninger. Trampolinhuset intervenerer således i København som et fysisk sted. Det er et alternativt kulturhus, hvor lovgivning og regler for asylansøgeres rammer i samfundet opløses med ønsket om at etablere en platform for demokratisk medborgerskab for brugerne. Trampolinhuset holder dog samtidigt fast $i$ at være en reel platform i samfundet. Rendells tilgang er her særligt interessant til at belyse, hvordan den konceptuelle intervention og kritik, sammen med udførsel at det reelle projekt, som Trampolinhuset er, bliver integreret i samfundets hverdagsliv som et alternativt rum til de eksisterende rammer på asylcentrene.

\section{Det diskursive rum}

Diskursanalyser er oftest forbundet med tekstuelle analyser fra samfundsvidenskab, kulturstudier og litteraturstudier. Spatiale analyser, der inkluderer diskursive analyser eller begreber, er ikke særligt udbredt. Det diskursive rum er oftest skabt af en kombination af handlinger, tekst, arkitektur og design, der er udtryk for rummets rationale. Ole B. Jensen (2004) fremlægger i artiklen Byen, Magten og Netvarket, at intertekstuel og lingvistisk repræsentation påvirker et steds diskurs og spiller en central rolle i den spatiale manifestation af et sted. Hegemonien på stedet er det rationale, der dominerer. Rationalet kan være privat, planlægningsmæssigt, offentligt eller indrammet af en event, en begivenhed eller et kulturelt steds interesser, og det dominerende rationale kan udfordres af andre rationaler på stedet (Jensen 2004, 56).

Denne opfattelse er på linje med kunsthistorikeren Miwon Kwons koncept om stedsspecificitet, hvor hun præsenterer stedets diskurs som en spatial komponent, der er fokuseret på formationen af rum som et socialt og diskursivt koncept. Kwon argumenterer for at stedsspecifik rumlig kunstnerisk praksis oftere og oftere søger et intenst engagement med dagligdagslivet og situationer udenfor kunstinstitutionen. Det sker ifølge Kwon 
fordi samtidens kunstpraksisser er interesserede $\mathrm{i}$ at adressere problemer og sociale udfordringer og skabe kunst, der er relateret direkte til aktuelle sociale problemer og steder (Kwon 2004, 24). Her er hun på linje med Rendell. Kwon bruger diskursivitet som koncept for at punktere den modernistiske myte om det uskyldige og uberørte sted, der ikke er influeret af interesser og betydning. Kwon vil illustrere, hvordan et sted har en stedsspecifik diskurs. Hun argumenterer for, at steder er struktureret intertekstuelt og derfor i højere grad skal læses, kortlægges og forstås som planer og oversigter end som et kort. Det vil sige som en fragmenteret sekvens af handlinger, events og tekst udført som rum, der skaber et nomadisk narrativ for stedet. (Kwon 2004, 13-29).

Det er nyttigt at sammenstille Jensen og Kwons diskursive modeller for stedsanalyse med Rendells critical spatial practice $i$ analysen af Trampolinhusets kritiske potentiale. Trampolinhuset kan forstås som en spatial kritisk praksis, da projektet med sin kombinerede kunstneriske og arkitektoniske praksis har interveneret i samfundet og lokalområdet i Københavns Nordvestområde. Projektet har udfoldet en social kritik, der er et modspil til det gældende politiske rationale i Danmark. Hvis vi læner os opad Jensen og Kwon, kan vi derudover forstå Trampolinhuset som havende et stedsspecifikt rationale, der relaterer sig til huset og til den socialpolitiske dagsorden. En dagsorden det frembringer som kunstprojekt. I det lys opfattes Trampolinhuset som en kritik og en rumlig kulturel moddiskurs.

Indbygget i Trampolinhuset ligger en risiko for at kritikken lukker sig om sig selv, hvis debatter og modstand primært foregår (inde) i huset. Risikoen for, at huset lukker sig om sig selv, kan f.eks. manifestere sig $i$, at brugerne gennem deres kritik ikke intervenerer i den nuværende politiske ramme, men tværtimod skaber et ekkokammer, hvor alle overordnet set er enige og ingen - praktiske og diskursive - forandringer finder sted. Et eksempel på huset engagement i omverdenen er udstillingsstedet Camp, der åbner huset for en bredere målgruppe. Et andet er i forbindelse med samspillet med Københavns Kommunes Områdefornyelse, hvor Trampolinhuset er engageret i lokalområdet i Nordvest. På den måde bringes aktiviteterne ud til en bredere målgruppe, der repræsenterer andre rationaler, og derved skabes der mulighed for at indgå i diskussioner og processer omkring forandring af den gældende politiske dagsorden.

\section{Kunstens sociale ansvar}

Det kunstneriske udgangspunkt for Trampolinhuset afstedkommer det krævende spørgsmål om kunstens i samfundet og mere specifikt, hvordan kunsten kan tage 'socialt ansvar'. I dette tilfælde bliver det gennem Rendells perspektiv tydeligt, at den kunstneriske proces her også sigter mod at skabe sociale muligheder, som beboerne ikke har på asylcentrene. De sociale muligheder for et værdigt hverdagsliv er netop det, som Trampolinhuset beskriver som et af sine kerneformål. 
Herved er der dog en risiko for, at opfattelsen af kunstens rolle i samfundet forbindes med løsningen af sociale opgaver. Er det overhovedet kunstens rolle? Den amerikanske kunsthistorieprofessor Claire Bishop beskriver i artiklen om begrebet Social Turn fra 2006, at der er opstået en social drejning i samtidskunstens fokus, som motiveres af neoliberale idealer, der sigter efter at bruge kunst og kultur som katalysator for økonomisk vækst (Bishop 2006). På denne måde fokuseres der således på kunstens nyttevirkning for samfundet og økonomien. Tendensen har b.la. taget afsæt i Storbritannien, hvor New Labour opfordrede kunsten til at være social, inkluderende og styrkende for samfundet gennem spørgsmålet: "Hvad kan kunst gøre for samfundet?". Bishop argumenterer for, at New Labours instrumentale tilgang til kunstområdet ikke skal fortolkes som en fejring af kunstnere og kunstneriske processer, men i stedet skal ses som en anerkendelse af kunst og kulturs evne til at engagere og motivere til entreprenørskab og selvorganisering (Bishop 2012, 15-16). Bishops pointe er, at der i disse processer opstår et antagonistisk forhold, hvor sociale grupper og deltagere i projekter involveres med en kynisk tilgang, hvor der fokuseres mere på selve værket, projektet og omtalen end på de involverede subjekter og deres agentur. Hun argumenterer for, at forskellige kunstværker og situationer inviterer til forskellige former for engagement, der kræver stor nænsomhed og omtanke omkring de involverede, hvilket må være omdrejningspunkt for en etisk diskussion omkring involvering og det agentur, kunstnere og kuratorer adresserer (Bishop 2012, 16).

Det belgiske filosof Chantal Mouffe har en mere optimistisk tilgang til, hvordan engagement gennem kunstprojekter kan forstås som en kritisk måde at bidrage til forandring af den gældende diskursive hegemoni i samfundet (Mouffe 2013). Hun ser et styrkende potentiale gennem dette engagement og fremlægger en strategi for, at der gennem kunstnerisk engagement i f.eks. byudviklingsprocesser kan opnås indflydelse og forandring ved, at individet engagerer sig i processen i stedet at stå uden for og udøve kritik. Hun opfordrer kunstneriske praksisser til at engagere sig i moddiskurser, da der netop i kunstens interventionistiske karakter findes et forandringspotentiale og derved en mulighed for at forandre den eksisterende neoliberale hegemoni (Mouffe 2013, 66-72). Gennem engagement er der mulighed for at skabe forandring. Mouffe kalder denne strategi for "agonisme med antagonisme", herved forstås en strategi baseret på kritik som engagement.

Kurator og kunstkritiker Andrea Phillips beskriver kunstens konfliktfyldte rolle og risiko som "caretaker", hvor socialt ansvar får et altoverskyggende fokus i kunsten. Konceptet kunst $\mathrm{i}$ det offentlige rum erstattes oftere og oftere af forskellige former for involverende, netværks- og samskabende praksisser. Hun argumenterer for, at denne situation er et paradoks, som kan forstås både vitalt og på samme tidspunkt fuldstændig destruktivt for den kunstneriske infrastrukturs opbygning. Hun betvivler de kunstneriske praksissers kritiske potentiale, hvis de orkestreres af diskursive og politiske agendaer (Phillips 2010). Phillips beskriver rollen for kunst i det offentlige rum som rekalibrering og omsorg for den offentlige sfæres ve og vel. Hun peger på, at kunst (og midler hertil) ofte ses instrumentaliseret, som elementer i post-velværdsstrategier og kalder på et mere kritisk blik på involverende og samskabende produktion (Phillips 2010, 55). Kunst er i 
dag i en situation, hvor den ikke længere kan regne med statsstøtte, men må genopfinde sig selv som en del af det neoliberalistiske felt. Philipps argumenterer for, at hvad, der opstår ud fra denne situation, er et forvirret felt, hvori neoliberalismens sprog og værdier integreres. Kulturprojekter opfordres alle til at co-producere, samskabe, netværke og skabe social sammenhæng og styrke i lokalområder (Phillips 2010, 38-40).

Bishop problematiserer på linje med Phillips kunstprojekter, der bruger mennesker som medie for deres intention og kritiserer den deltagende og engagerende tendens. Hun anerkender, at der i deltagende projekter også er entusiasme, nysgerrighed og engagement fra deltagerne, men stiller spørgsmål til både det etiske aspekt samt den overfladiske behandling af deltagere i denne type projekter. Deltagerne bliver, hvad hun døber "delegerede performere", og hun kritiserer, at kunstnere vælger at bruge mennesker som materiale f.eks. til at undersøge kollektiv identitet. Bishop argumenterer for, at risikoen for at udføre denne proces overfladisk og misbruge deltagernes engagement som arbejdskraft i stedet for de kunstneriske samarbejdspartnere, som de kan være, er stor (Bishop 2012, 234).

De nye inddragende praksisser, hvor kunstprojekter spiller en social rolle i samfundet, har dog ifølge Phillips et potentiale, hvor de belyser, oversætter, fejrer og kritiserer samfundet og politiske diskurser ved at engagere sig i dem, på linje med Mouffes agenda. Hun konkluderer, at hvis kunst har kapaciteten til at genopfinde sin position som kunst i det offentlige rum i samfundets nuværende diskurs, så bør kunsten gøre det og tage muligheden alvorligt. Hvis kunstnere, kuratorer m.fl. drager nytte af deres position og engagerer sig i politiske diskurser for at skabe forandring, kan det potentielt være begyndelsen på nye tværdisciplinære praksisser mellem kunst, politik og samfund (Phillips 2010, 53).

Vender vi tilbage til Trampolinhuset og betragter det med et kunstkritisk blik, så er huset i en situation, hvor samfundet formodentlig har 'glemt', at det startede som et kunstprojekt. Det ses som et medborgerhus drevet med social ansvarlighed. Ud fra det perspektiv, så er der umiddelbart ikke risiko for, at brugerne på uetisk vis udnyttes som en del af et kunstværk, der skal promoveres. Omvendt har udgangspunktet som kunstprojekt fået en sekundær rolle, da projekt nu hovedsageligt er en social agent på vegne af en målgruppe, en politisk moddiskurs og et reelt frirum for brugerne. Initiativtagerne har på interessant vis valgt at genlancere kunst $i$ Trampolinhuset med det integrerede udstillingssted Camp. Dette initiativ kan tolkes som en insisteren på kunstens potentiale i det politiske rum for diskussioner og forandring.

\section{Rumlig kritik som politisk modspil?}

Er Trampolinhuset et eksempel på en tværdisciplinær praksis, der med udgangspunkt i kunsten bliver en politisk moddiskurs? Det kunstneriske har været udgangspunktet og har stadig en stor rolle i husets integrerede kunstcenter og insisteren på tilstedeværelsen af kunstnerisk metode og praksis. Samtidig arbejder projektet med politiske og sociale 
aspekter i flygtningedebatten og kan således opfattes som tværdisciplinært. I dag har Trampolinhuset et dagligdagsliv med aktiviteter, der giver rammer og fællesskab for dets brugere. Ambitionen med aktiviteterne er stadigt et politisk modspil til den gældende politiske agenda på asylområdet og kan således forsat forstås som et frirum over for det eksisterende system og er samtidigt et alternativt politisk rum. Altså det tredje rum, som initiativtagerne sigtede efter.

Det teoretiske blik på rummets etablering, som Rendell, Jensen og Kwon tilbyder, er et blik, hvor dagligdagsaktiviteter kan forstås både som almindelig praksis, der etablerer rum og samtidig som en kritik og rekalibrering af den gældende politiske diskurs. Dette da dagligdagsaktiviteterne er kurateret som mentalt styrkende og faktisk ikke alle er juridisk tilladt for den gruppe, de udbydes til. Derved får de en frisættende betydning, bidrager til et meningsfyldt liv for brugerne og giver huset en aktivistisk dimension.

Imidlertid er det relevant at stille spørgsmål til, om Trampolinhuset overhovedet iværksætter en forandring af det gældende politiske rationale. Husets brugere er asylansøgere, frivillige og aktivister. Der er altså tale om en gruppe mennesker, der overordnet set er enige i, at de politiske rammer er udfordrende. Derfor er der risiko for, at udfoldelsen bliver et ekkokammer, hvor initiativtagerne skaber dialog med ligesindede og dermed ikke påvirker den politiske diskurs. Imidlertid findes der en række strategiske samarbejder, hvor vision og metode formidles uden for huset i nye kontekster. Desuden er huset indgået i samarbejde med og modtager støtte fra i Københavns Kommune, som kan være starten på et stabilt rodnet i området og en langsigtet strategi som systemkritisk aktør i den københavnske arena.

Og så er der kunstens rolle. I huset er der forsat sikret plads til kunsten gennem et decideret kunstcenter. Kunst vurderes således her at have en central rolle, når det handler om at etablere kritiske og alternative rum. Den kan stille spørgsmål, danne nye fællesskaber og være afsæt for at skabe rum for refleksion og invitere nye grupper ind i huset. Det er ikke i alle henseender kunsten, der er på dagsordenen i Trampolinhuset, men den kan krediteres for at være det eksperimenterende afsæt for stedets evne til at skabe en rumlig kritisk praksis. Projektet er også forskelligt fra den kritiske og socialt engagerede kunst, som er bredt repræsenteret og teoretiseret i kunstfeltet. Her er tendensen, at projekterne ofte er af symbolsk og midlertidig karakter. Eksempler herpå er den danske kunstnergruppe SUPERFLEX, som b.la. har lavet en bredt distribueret plakat med teksten "Foreigners. Please don't leave us alone with the Danes". Samt det tyske arkitektkollektiv Raumlabor, som fokuserer deres socialt engagerede og rumlige praksis på at intervenere midlertidigt i belastede byudviklingsområder for at foreslå forandringer. Disse praksisser er også kritisk orienterede og socialt engagerede, men fokuserer i højere grad på interventionens og det æstetiskes kraft i deres projekter, som de kritiske og politiske projekter baner vejen for. Der findes også andre eksempler på projekter, der i tråd med Trampolinhusets metode integrerer sig som sociale agenter i lokale og nationale kontekster. Det er bl.a. den Østrigske kunstgruppe Wochenklausur, som har lavet en mobil lægeklinik for hjemløse, der kører rundt i Wiens gader. Andre eksempler er kunstinstitutioner i belastede 
lokalområder som f.eks. Tensta Konsthall uden for Stockholm eller den meget nyetablerede vision om en kunsthal i Gellerupparken i Aarhus, som også er eksempler på, hvordan kunst opfattes som en potentielt stærk forandringskapacitet på social- og boligområdet.

Trampolinhuset fremstår som et eksempel på kunstens evne til at skabe en spatial politisk kritik og et frirum uden for kunstinstitutionen. Måske er det endnu for tidligt at sige præcist, hvordan dette frirum og denne kritik skaber forandring, men idet huset trods dets systemkritiske ideer har opnået ekstern - herunder kommunal og statslig - støtte og opbakning, er det nærliggende at argumentere for, at det som politisk spiller må tages seriøst.

Litteratur:

Bishop, C. (2012). Artificial Hells: Participatory Art and Spectatorship. New York: Verso.

Bishop, C. (2006). The Social Turn: Collaboration and its Discontents. New York: Art Forum.

Blankholm, L. (2011). Trampolinhuset: Fristed og forsamlingshus. Modkraft. Tilgængelig på: http://modkraft.dk/node/14931 [Tilgået 01.10.18]

Bonde, L. (2011). Kunst i det godes tjeneste. Weekendavisen, 24. marts 2011.

Goll, M. (2017). Trampolinhuset: demokratisk medborgerskab øger integrationen. Altinget. Tilgængelig på: https://www.altinget.dk/arbejdsmarked/artikel/trampolinhuset-demokratisk-medborgerskab-oeger-integrationen [Tilgået 01.10.18]

Wehl, S.B. and Hansen, F. (2018). Interview med Frederikke Hansen, 25.09.2018.

Jensen, O. B. (2004). Byen, magten og netværket. Dansk Sociologi, årg. 15(3), s. 53-65.

Klokhøj, J. (2011). Studerende giver asylansøgere en stemme. Uniavisen. Tilgængelig på: https://uniavisen.dk/studerende-giver-asylansoegere-en-stemme/ [Tilgået 01.10.18]

Kristensen, B. F. (2016). Trampolinhuset: »Vi tilbyder nogle gange lidt mere nær hjælp. Vi er ikke en del af systemet«. Politiken. Tilgængelig på: https://politiken.dk/indland/samfund/art5619923/Trampolinhuset-\%C2\%BBVi-tilbyder-nogle-gangeen-lidt-mere-n\%C3\%A6r-hj\%C3\%A6lp.-Vi-er-ikke-en-del-af-systemet $\% \mathrm{C} 2 \% \mathrm{AB}$ [Tilgået 01.10.18]

Kwon, M. (2004). One Place After Another. Cambridge, Mass.: MIT Press.

Mouffe, C. (2013). Agnostics - Thinking the World Politically. London: Verso.

Phillips, A. (2010). Too Careful: Contemporary Arts Public Making. I: Phillips, A. and Miessen (eds.), Actors, Agents and Attendants: Caring Culture: Art, Architecture and Politics of Public Health. M. Amsterdam: Sternberg Press, s. 35-56.

Rendell, J. (2006). Art and Architecture: A Place Between. London: I. B. Tauris. 